\title{
FORMATION OF COMPETENCES OF STUDENTS OF TECHNICAL SPECIALTIES IN THE PROCESS OF THEIR FUNDAMENTAL MATHEMATICAL TRAINING
}

\author{
Alona Kolomiiets \\ Vinnitsa National Technical University, Ukraine \\ Vitalii Klochko \\ Vinnitsa National Technical University, Ukraine
}

Olena Stakhova

Vinnitsya Institute of Economics and Social Sciences of the higher educational establishment “Open International University of Human Development “Ukraine”, Ukraine

\begin{abstract}
The classification of competences of graduates of secondary and higher technical educational establishments is presented in the work. On the basis of the list of professional and mathematical competences offered by scientists, the professional-oriented mathematical competences of the future specialist, the most important and relevant for the professional activity of future engineers, are allocated. These include: conceptual, operational-algorithmic, applicable, design.

The purpose of the article is to describe an experimental verification of the professionallyoriented mathematical competencies formation of future specialists in the electronics and telecommunications industry. The main research methods used by the authors: theoretical methods: analysis, synthesis, comparison and generalization of the research results of scientific and methodological literature on selected issues; empirical: observation, experiment, questionnaire, analysis of the obtained test results.

During the study of higher mathematics, students are encouraged to take actions that promote the formation of skills that are part of mathematical competences. These actions are also performed by the engineer, he also needs to be able to analyze, synthesize, classify. Therefore, the formation of the above mathematical competences is appropriate and necessary for the professional training of the engineer.
\end{abstract}

Keywords: competence, fundamental mathematical training, professionally directed mathematical competence, students of technical specialities.

\section{Introduction}

Mathematical training for a technical specialist is the key to professionalism. The present society makes high demands on the level of professional culture of a specialist in the technical field, and the high level of the public environment 
Kolomiiets et al., 2020. Formation of Competences of Students of Technical Specialties in the Process of their Fundamental Mathematical Training

informatization determines the focus on the formation, in particular, of a high level of mathematical training for future specialists in technical specialties.

Therefore, it is important for a specialist in a technical field - a graduate of a technical educational institution - to have an established system of knowledge and skills that will contribute to professional activity. For the future engineer, the prevailing professional competencies are of paramount importance, which are inextricably linked with the formation of fundamental mathematical competencies. Since the level of engineer professionalism is due to the possession and application of the mathematical methods in professional activity, special attention is paid to the formation of professionally directed mathematical competencies. At the same time, the formation of professional competencies correlates with the acquisition of fundamental knowledge and skills in mathematics.

Based on these considerations, the aim of the article is to highlight, justify and describe the experimental verification of the formation of some professionally directed mathematical competencies of technical specialties students in the process of fundamental mathematical preparation. The main research methods used by the authors are: theoretical methods (analysis, synthesis, comparison and generalization of the research results of scientific and methodological literature on selected issues); empirical (observation, experiment, questionnaire, analysis of the obtained test results.

\section{Content of article}

The problems of the mathematical competencies formation were considered in their studies by B. Alpers (2013) (highlighted mathematical competencies in the training programs for future engineers), M. Kovtonyuk (2013) (in the general professional training of a mathematics teacher), S. Rakov (2005) (a mathematics teacher based on a research approach to teaching using information technologies), T. Yarkho (2016) (formation of mathematical competencies in students of technical specialties in the process of fundamentalization of mathematical preparation), G. Dutka (2009) (introduction principle of fundamentalization in the process of future economists mathematical training) and many other scientists.

As S. Rakov notes, "the system of competencies in education has a hierarchical structure” (S. Rakov, 2005, p.32). The scientist lists a number of competencies identified in the education system: key, general and brunch, subject. At the same time, the researcher notes the necessity to determine lower level competencies in such a way that they together provide the highest level competence. Meanwhile, the scientist relates to subject-branch mathematical competencies: procedural, logically technological, research, methodological (Rakov, 2005, p.39-41). 
The article presented the mathematical competencies of future engineers listed by B. Alpers (B. Alpers, 2013) in the curriculum: mathematical thinking, mathematical reasoning, formulation and solution of mathematical problems, mathematical modeling, processing of mathematical symbols, mathematical communication, creation of auxiliary tools and instruments (Kolomiiets, Klochko, \& Stakhova, 2019, p. 88).

In the study of researcher $\mathrm{M}$. Kovtonyuk the competence of a future mathematics teacher is conveyed. General (key) competencies: social and personal, instrumental, general scientific; professional competencies: special, methodological, psychological and pedagogical (Kovtonyuk, 2013).

Monitoring of educational training programs (ETP) of bachelors at Vinnytsia National Technical University (VNTU) and Vinnytsia Technical College (VTC) led to the conclusion that for students of all specialties highlighted are almost identical competencies that a graduate should have (Table 1).

Table 1 Comparison of the proposed competencies of future engineers of Vinnytsia National Technical University (VNTU) and Vinnytsia Technical College (VTC)

\begin{tabular}{|c|c|c|c|c|}
\hline \multirow{4}{*}{ 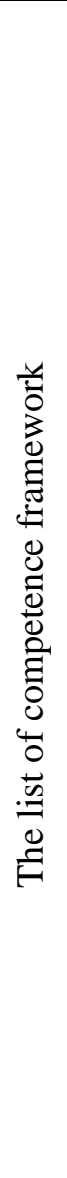 } & $\begin{array}{l}\text { Vinnytsia National } \\
\text { Technical University } \\
\text { (VNTU) }\end{array}$ & $\begin{array}{l}\text { The name of } \\
\text { educational training } \\
\text { programs (ETP), } \\
\text { specialty }\end{array}$ & $\begin{array}{l}\text { Vinnytsia Technical } \\
\text { College (VTC) }\end{array}$ & $\begin{array}{l}\text { The name of } \\
\text { educational training } \\
\text { programs (ETP), } \\
\text { specialty }\end{array}$ \\
\hline & $\begin{array}{l}\text { Social and personal, } \\
\text { general scientific, } \\
\text { instrumental; } \\
\text { professional: } \\
\text { generally } \\
\text { professional, } \\
\text { specialized } \\
\text { professional }\end{array}$ & $\begin{array}{l}\text { Electric power and } \\
\text { Electric engineering } \\
141 \text { - Electric power } \\
\text { Electric engineering } \\
\text { and } \\
\text { electromechanics }\end{array}$ & $\begin{array}{l}\text { Integral, social and } \\
\text { personal, } \\
\text { instrumental, } \\
\text { general, } \\
\text { professional: } \\
\text { generally } \\
\text { professional, } \\
\text { specialized } \\
\text { professional }\end{array}$ & $\begin{array}{l}\text { Maintenance and } \\
\text { repair of renewable } \\
\text { energy plant } \\
\text { 141- Electric power } \\
\text { Electric engineering } \\
\text { and } \\
\text { electromechanics }\end{array}$ \\
\hline & $\begin{array}{l}\text { Integral } \\
\text { competency, } \\
\text { general, special } \\
\text { (professional) } \\
\text { competencies }\end{array}$ & $\begin{array}{l}\text { Telecommunication } \\
\text { Radio technology } \\
172- \\
\text { Telecommunication } \\
\text { and radio } \\
\text { technology }\end{array}$ & $\begin{array}{l}\text { Integral, social and } \\
\text { personal, } \\
\text { instrumental, } \\
\text { general, generally } \\
\text { professional, } \\
\text { specialized } \\
\text { professional }\end{array}$ & $\begin{array}{l}\text { Constructing, } \\
\text { manufacture and } \\
\text { maintenance of } \\
\text { radio devices } \\
172- \\
\text { Telecommunication } \\
\text { and radio } \\
\text { technology }\end{array}$ \\
\hline & $\begin{array}{l}\text { General, } \\
\text { professional }\end{array}$ & $\begin{array}{l}\text { Computer } \\
\text { engineering } \\
123 \text { - Computer } \\
\text { engineering }\end{array}$ & $\begin{array}{l}\text { Integral competence, } \\
\text { General } \\
\text { competences, } \\
\text { Professional } \\
\text { competences }\end{array}$ & $\begin{array}{l}\text { Maintenance of } \\
\text { computer systems } \\
\text { and networks } \\
123 \text { - Computer } \\
\text { engineering }\end{array}$ \\
\hline
\end{tabular}


Kolomiiets et al., 2020. Formation of Competences of Students of Technical Specialties in the Process of their Fundamental Mathematical Training

Summarizing the result of the analysis of the competencies proposed for mastering the educational and professional programs of VNTU, VTC, system of competencies that a future engineer should master are presented, they are: social and personal (SPC), general scientific (GSC), instrumental (IC), generally professional (GPC) and specialized professional (PCB).

The formation of mathematical competencies in the "pure state" is found among general scientific competencies. However, the analysis of professional programs shows the existence of a description of the applied mathematical competencies to the solution of professionally oriented problems. So, for example, general scientific competence is used for the formation of students future engineers - the ability to apply mathematical knowledge in the process of solving professional tasks, building mathematical models.

An analysis of the general educational professional and specialized professional competencies formulated in educational and professional programs for the formation of the educational process allows concluding that not only mathematical competencies, but also skills are formed during the fundamental mathematical training of students, and are broader and cover a certain part of the abilities provided for in general professional and specialized professional competencies.

So, among special professional competencies "the ability to apply knowledge to solve specialized problems and practical problems in the field of professional activity", based quite often on solving a mathematical model. It should also be added that in the process of fundamental mathematical training, students acquire skills in constructing algorithms for solving mathematical and stagnation problems, mainly professionally oriented. Therefore, in the process of fundamental mathematical training of technical specialists, the formation of mathematical competencies occurs, which include the components of general professional and specialized professional competencies. In the context of this idea, we single out professionally directed mathematical competencies, the formation of which will predetermine the professional level of the future engineer.

According to the article, professionally directed mathematical competenciesinclude: conceptual, operationallyalgorithmic, applicable, design (Kolomiiets, Klochko, \& Stakhova, 2019).

Part of operational and algorithmic competence is the ability to classify and systematize objects, concepts, classify them according to a specific attribute, generalizing their properties, and establish connections between them.The systematization of concepts as a criterion for obtaining competencies, a number of researchers, including S. Rakov (2005) put at the highest level of mastery the relevant competencies. That is, the ability to classify and systematize a concept is an indicator of a high level of achievement. 
The systematic assignment of objects to a certain group of objects, connected by a certain sign and criterion forms a systematization skill among students and the ability to systematize objects a priori implies a high level of students' conceptual competencies (theoretical mathematical knowledge and skills in their application).

The systematization of the knowledge and skills of students and learners was given great attention in the studies of psychologists and teachers: O. Leontyeva (1983), P. Halperina (2002), S. Slepkan (1983), and others. The main result of the systematization process is such a quality of knowledge as consistency, which provides for a holistic, systemic assimilation of the material, awareness of leading ideas and principles that play the role of the main strategic factors in all intrasubject and inter-subject communications of this subject content. As it was studied, if objects are located in a strictly thought-out system, then their perception requires minimal effort; chaotic location requires more volitional efforts. (Stakhova, 2013)

Schemes reflecting the relationship between concepts make it possible to better store new information in memory. In the diagrams and tables, not only the elements of the system are highlighted, but the system-forming relationships between them are also reflected.

The methodology of forming the classification and systematization skills in the process of fundamental mathematical preparation consists in a system of targeted student actions, managed by a teacher. The student, as the subject of the educational process, constantly accumulates teaching information.

The process of constantly assigning information to a specific group of information blocks contributes to their better memorization. "Systematization allowing more productive use of the memory, as eliminates the need to memorize information as the sum of the individual information and facts, by grouping them into larger units, it is better to keep in the mind and, if necessary, to reproduce." (Stakhova, 2013).

The acquired ability of students to systematize material in the process of fundamentalizing mathematical training is basis of skills and abilities to clearly systematize and classify information of a professional nature, since the same mental actions correspond to both "systematizations". In addition, for a future specialist in the field of electronics and telecommunications, the ability to classify and systematize information and objects helps in finding a choice of the error place, localization of the accident, and quickly correcting the situation.

The formation of the ability to classify and systematize objects is integrated into the entire educational process, and mathematical training in particular. So, in the higher mathematics class the teacher constantly encourages students to classify and systematize objects. 
Kolomiiets et al., 2020. Formation of Competences of Students of Technical Specialties in the Process of their Fundamental Mathematical Training

In the order to verify the methodology of the ability of students to systematize and classify, which are components of operational and algorithmic competence, the groups of students where the experiment was conducted, were divided into two groups: experimental and control. Both groups of students were chosen arbitrarily, had equal opportunities, and together attended lectures on the subject "Higher Mathematics". The difference was that in the experimental group the proprietary methodology was introduced. One of the elements was a systematic training in the methods of classification and systematization of educational material (any topic), detailed repetition, synthesis, classification and generalization of the material.

Special tables have been created and filled. See Table. 2 Systematization and classification of differential equations and methods for solving them.

Students in each lesson repeated the previous theoretical and practical material, received new material, analysed it, classified and systematized, made comparisons of the information received, for example.

Classification and systematization as mental actions directly related to the processes of thinking: analysis, synthesis, comparison, abstraction, generalization.

The ability to correlate a differential equation to a specific type was checked on a test form. During the test, several differential equations was offered to a student, that need to be attributed to one or another type, as well as to give a method for solving them.

\section{Table 2 Systematization and classification of differential equations and methods for solving them}

\begin{tabular}{|l|l|l|l|l|}
\hline $\begin{array}{c}\text { Type of } \\
\text { differential } \\
\text { equation }\end{array}$ & \multicolumn{1}{|c|}{ Form } & Solution method & Example & $\begin{array}{l}\text { Skills acquired } \\
\text { by the student }\end{array}$ \\
\hline $\begin{array}{l}\text { Differential } \\
\text { equation with } \\
\text { separable } \\
\text { variables }\end{array}$ & $\begin{array}{l}\text { The function of the } \\
\text { argument } x \\
\text { multiplied by the } \\
\text { differential } d x \text {, and } \\
\text { the function of the } \\
\text { argument } y \\
\text { multiplied by } d y .\end{array}$ & $\begin{array}{l}\text { differential equation } \\
f(x) d x=\varphi(y) d y \\
\text { sides of the }\end{array}$ & $\begin{array}{l}\text { cos } x d x=y^{3} d y \\
f(x) d x=\int \varphi(y) d y\end{array}$ & $\begin{array}{l}\text { The ability to } \\
\text { correlate a } \\
\text { concept in a } \\
\text { known set of } \\
\text { concepts } \\
\text { according to } \\
\text { certain } \\
\text { characteristics. }\end{array}$ \\
\hline
\end{tabular}




\begin{tabular}{|c|c|c|c|c|}
\hline $\begin{array}{l}\text { Differential } \\
\text { equation with } \\
\text { separable } \\
\text { variables }\end{array}$ & $\begin{array}{l}f_{1}(x) \phi_{1}(y) d x= \\
=f_{2}(x) \phi_{2}(y) d y\end{array}$ & $\begin{array}{l}\text { Using mathematical } \\
\text { transformations, } \\
\text { dividing the both } \\
\text { sides of the equation } \\
\varphi_{1}(y) f_{2}(x) d y \\
\text { differential equation } \\
\text { with separable } \\
\text { variables will be } \\
\text { obtained }\end{array}$ & $\begin{array}{l}\operatorname{arctg} x \cdot \sqrt{y} d x= \\
=\left(1+x^{2}\right) \cdot y^{2} d y ; \\
\frac{\operatorname{arctg} x \cdot \sqrt{y}}{\left(1+x^{2}\right) \cdot \sqrt{y}} d x= \\
=\frac{\left(1+x^{2}\right) \cdot y^{2}}{\left(1+x^{2}\right) \cdot \sqrt{y}} d y ; \\
\frac{\operatorname{arctg} x}{\left(1+x^{2}\right)} d x= \\
=\frac{y^{2}}{\sqrt{y}} d y ; \\
\frac{\operatorname{arctg} x}{\left(1+x^{2}\right)} d x=y^{\frac{3}{2}} d y \\
\int \frac{\operatorname{arctg} x}{\left(1+x^{2}\right)} d x=\int y^{\frac{3}{2}} d y \\
\ln (\operatorname{arctg} x)+C=\frac{2 y^{\frac{5}{2}}}{5}\end{array}$ & $\begin{array}{l}\text { The ability to } \\
\text { correlate a } \\
\text { concept in a } \\
\text { known set of } \\
\text { concepts } \\
\text { according to } \\
\text { certain } \\
\text { characteristics, } \\
\text { the ability to } \\
\text { distinguish the } \\
\text { characteristics } \\
\text { of elements } \\
\text { and, on the } \\
\text { basis of this, to } \\
\text { separate } \\
\text { elements }\end{array}$ \\
\hline $\begin{array}{l}\text { Homogeneou } \\
\mathrm{s} \text { differential } \\
\text { equation }\end{array}$ & $\begin{array}{l}\text { Checking if the } \\
\text { differential } \\
\text { equation belongs to } \\
\text { the type of } \\
\text { homogeneous by } \\
\text { substitution } \\
\varphi(x t, y t) d x=\varphi(x, y\end{array}$ & $\begin{array}{l}\text { Appling substitution } \\
\frac{y}{x}=U \\
y=U \cdot x \\
y^{\prime}=U^{\prime} \cdot x+U \\
\text { Such a substitution } \\
\text { reduces } \\
\text { homogeneous } \\
\text { equation to a } \\
\text { differential equation } \\
\text { with separable } \\
\text { variables th with } \\
\text { respect to the } \\
\text { variables } \\
x \text { and } U\end{array}$ & $\begin{array}{l}y^{\prime}=2 \sqrt{1+\left(\frac{y}{x}\right)^{2}}+\frac{y}{x} \\
\text { Make a replacement } \\
\frac{y}{x}=U \\
y=U \cdot x \\
y^{\prime}=U^{\prime} \cdot x+U \\
U^{\prime} \cdot x+U= \\
=2 \sqrt{1+(U)^{2}}+U \\
\frac{d U}{d x} \cdot x+U= \\
=2 \sqrt{1+(U)^{2}}+U \\
x \frac{d U}{d x}=2 \sqrt{1+(U)^{2}} \\
\frac{d U}{\sqrt{1+(U)^{2}}}=2 \frac{d x}{x} \\
\ln \left|U+\sqrt{1+(U)^{2}}\right|= \\
=2 \ln |x|+\ln C\end{array}$ & $\begin{array}{l}\text { The ability to } \\
\text { correlate a } \\
\text { concept in a } \\
\text { well-known set } \\
\text { of concepts } \\
\text { according to } \\
\text { certain } \\
\text { characteristics, } \\
\text { knowledge of } \\
\text { methods for } \\
\text { assessing the } \\
\text { characteristics } \\
\text { of separate } \\
\text { elements }\end{array}$ \\
\hline
\end{tabular}


Kolomiiets et al., 2020. Formation of Competences of Students of Technical Specialties in the Process of their Fundamental Mathematical Training

\begin{tabular}{|l|l|l|l|}
\hline & $\begin{array}{l}U+\sqrt{1+(U)^{2}}=x^{2} \cdot C \\
\frac{y}{x}+\sqrt{1+\left(\frac{y}{x}\right)^{2}}=x^{2} \cdot C\end{array}$ & \\
\hline
\end{tabular}

To evaluate the effectiveness of the proposed approach to the formation of the knowledge element "systematization and classification of the material" in the experimental and control groups in the first semester exam, students were asked to undergo testing. Testing consisted of several blocks. In the block "Differential equations" the student was offered differential equations, for each it was necessary to establish the type and write down the algorithm for solving it (Table 3). Students have to perform the following steps:

1. Determine what kind the differential equation belongs to

2. Specify the solution method

Table 3 The example of individual work on the topic "Differential equations"

\begin{tabular}{|l|l|l|}
\hline \multirow{2}{*}{ 1. $y^{\prime}=\frac{y}{x}+\cos \frac{y}{x}$} & \multicolumn{1}{|c|}{$\begin{array}{c}\text { Type of differential } \\
\text { equation }\end{array}$} & \multicolumn{2}{|c|}{ Solution method } \\
\hline & $\begin{array}{l}\text { Homogeneous } \\
\text { differential equation }\end{array}$ & $\begin{array}{l}\text { We have to us the substitution } \\
U=\frac{y}{x}, y=U \cdot x, y^{\prime}=U^{\prime} \cdot x+U\end{array}$ \\
\hline 2. $y^{\prime \prime}-5 y^{\prime}+4 y=(5 x-1) e^{4 x}$ & & \\
\hline$\frac{d^{2} y}{d x^{2}}+\frac{d y}{d x}-6 y=0$ & & \\
\hline 4. $\left(x^{2}+1\right) d y=x y d x$ & & \\
\hline 5. $y^{\prime}+4 y-2=0$ & & \\
\hline 6. $x^{2} y^{\prime}-2 x y=3 x^{2}$ & & \\
\hline 7. ${ }^{\operatorname{tg} x} \sqrt{y} d x=x y^{2} d y$ & & \\
\hline 8. $y^{\prime \prime}=x$ & & \\
\hline
\end{tabular}

In front of each proposed differential equation, students indicate their type and write down the appropriate method for solving it.

According to certain criteria (completeness, correctness, accuracy), the answer of the student was attributed to the appropriate level. Thus, every student 
answer was assigned to one of four levels: high, sufficient, medium, low. So, the skill of classification and systematization was evaluated at four levels.

High level is characterized by clarity, completeness of the answer. The student correctly indicated the types of all the proposed differential equations, correctly established the methods for solving them, the answer contains the clarity and consistency of the material presentation.

Sufficient level. The student determines the types of differential equations but can be mistaken in the algorithm of the method for solving them, allows inaccuracies in explaining the solution of the equation. The student response is characterized by logic, correctness with some inaccuracies.

Middle level. The student has general ideas about differential equations, distinguishes differential equation of first-order and second-order in the number of derivatives. But it is often mistaken in the types of differential equations and methods for solving them; it does not accurately determine the type of differential equation or the method for solving a differential equation.

Low level. The student cannot accurately indicate the type of differential equation, guesses the type of differential equation, most often according to the form, usually correctly indicates the name of the linear inhomogeneous differential equation, but does not know the method for solving it. There are no skills in solving the corresponding characteristic equation of a linear homogeneous differential equation.

According to the test results, the answers of students in the control and experimental groups were distributed as follows: Table 4.

Table 4 Comparison of the development level of classification and systematization abilities in the experimental and control groups

\begin{tabular}{|c|c|c|c|c|c|c|c|c|}
\hline & \multicolumn{10}{|c|}{ Experiment results } \\
\cline { 2 - 10 } & H & $\mathbf{9}$ & S & $\mathbf{\%}$ & M & $\mathbf{\%}$ & L & $\mathbf{\%}$ \\
\hline Control group & 7 & $\mathbf{9}$ & 13 & $\mathbf{1 6}$ & 14 & $\mathbf{1 8}$ & 45 & $\mathbf{5 7}$ \\
\hline Experimental group & 13 & $\mathbf{5 7}$ & 1 & $\mathbf{4}$ & 6 & $\mathbf{2 6}$ & 14 & $\mathbf{1 4}$ \\
\hline
\end{tabular}

The results are shown using the diagram (Figure 1). 
Kolomiiets et al., 2020. Formation of Competences of Students of Technical Specialties in the Process of their Fundamental Mathematical Training

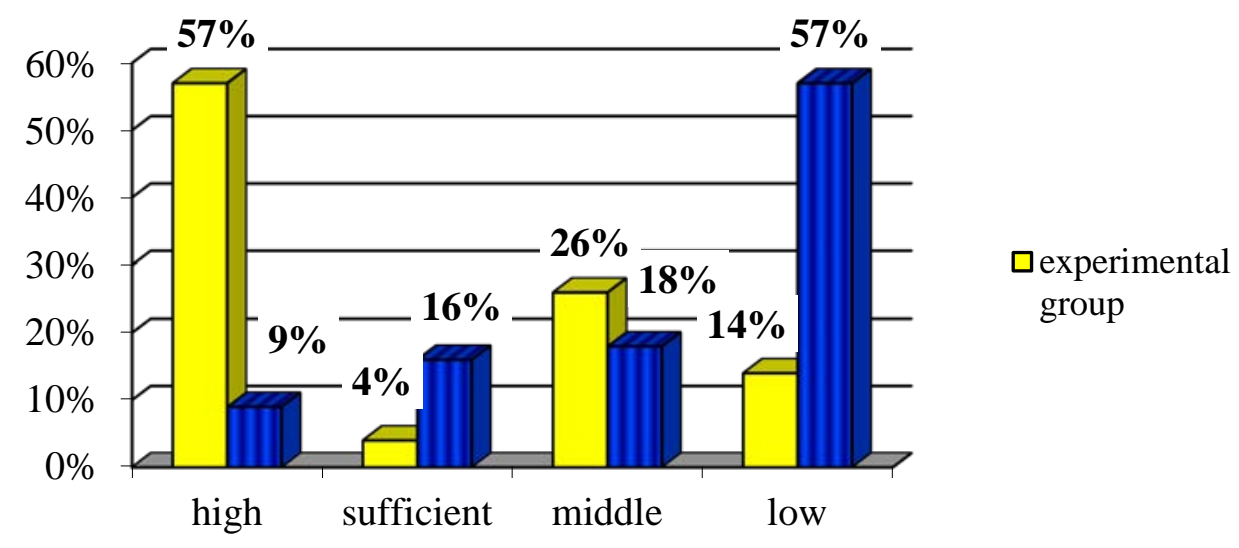

Figure 1 Comparative analysis of students' ability to classify and systematize

\section{Conclusions}

1. Given the analysis of the scientific literature on the problem of highlighting the competency system, the analysis of educational and professional programs for students of technical specialties, it was identified a number of professionally directed mathematical competencies that are formed by students of technical specialties in the process of their fundamental mathematical preparation: conceptual; operationally algorithmic; applicable design.

2. Professionally directed mathematical competencies are formed in the process of fundamental mathematical training of specialists in technical specialties and include components of professional and specialized professional competencies.

3. The ability to systematize and classify objects according to a specific criterion belongs to the operationally algorithmic competencies of a specialist in a technical field and is important in the professional activity of a specialist.

4. Based on the results of the experiment, the introduction of elements of the author's methodology into the educational process, it is concluded: we have more students of high and sufficient skill levels in the experimental group than in the control group. The difference between these two groups is $36 \%$. And this gives reason to argue about the effectiveness of the proposed methodology. 


\section{References}

Alpers, B. (2013). A Framework for Mathematics Curricula in Engineering Education. A Report of the Mathematics Working Group. Brussels: European Society for Engineering Education.

Dutka, G. (2009). The principle of fundamentalization and its implementation in the mathematical training of future economists: dissertation abstract... Dortor of Education Institute of Teacher Education and Adult Education. K.

Halperin, P. (2002). Lectures on Psychology / Edited and with foreword by A.I. Podolsky. M.

Klochko, V., \& Kovalchuk, M. (2009). Computer-based methodology for generalizing and systematizing knowledge and skills in the process of teaching students of analytical geometry: a monograph. Vinnytsia: VNTU.

Klochko, V. (2017). Formation of mathematical competencies of students of technical universities. Scientific journal M.P. Drahomanova NPU, Kiev, Series No. 2. Computeroriented learning systems: Collection of research papers, 9(26), 64-67.

Kovtonyuk, M. (2013). Fundamentalization of vocational training of a future mathematics teacher - bachelor: monograph. Vinnytsia LLD company "Planer".

Kolomiiets, A., Klochko, V., \& Stakhova, O. (2019). Professionally oriented tasks as a component of the fundamental mathematical training of students of technical universities and colleges. Pedagogical Discourse, 26, 85-93.

Leontyev, A. (1983). Selected psychological works, Volume 1. Moscow: Publishing House "Pedagogy".

Marchenko, O. (2007). Systematization of knowledge of high school students in the process of teaching mathematics with computer support: dissertation abstract... PhD in Pedagogy. Kiyv.

Petruk, V. (2006). Theoretical and methodological foundations of the formation of professional competence of future specialists in technical specialties in the process of studying fundamental disciplines: monograph. Vinnytsia: "Universum-Vinnytsia".

Rakov, S. (2005). The formation of the mathematical competencies of a mathematics teacher based on a research approach to teaching using information technology: dissertation... Dortor / H.S. Skovoroda Kharkiv National Pedagogical University.

Slepkan, Z. (1983). Psychological and pedagogical foundaitions of mathematics. L.: Soviet school.

Stakhova, O. (2013). Professional and creative development of a future junior specialist in technical profile in the process of vocational training [Text]: dissertation ... Vinnytsia Mykhailo Kotsiubynskyi State Pedagogical University - Vinnytsia.

Yarho, T. (2016). Fundamentalization of the mathematical training of future technical specialists in higher educational institutions: monograph. Kharkiv National Automobile and Highway University Kharkiv: KhNAHU. 